Int Arch Allergy Immunol 1994; 104:I-IV

\title{
Contents, Vol. 104, 1994
}

\section{No. 1}

Discordant Expression of LFA-1, VLA-4 $\alpha$, VLA-ß1, CD45RO 17 and CD28 on T-Cell Subsets: Evidence for Multiple Subsets of 'Memory'T Cells Kern, F.; Döcke, W.D.; Reinke, P.; Volk, H.D.

Effects of Conjunctival Hyperosmolar Challenge in Allergic

Subjects and Normal Controls

Ciprandi, G; Buscaglia, S.; Pesce, G; Lotti, R.; Rolando, M.;

Bagnasco, M.; Canonica, GW.

Short Communications

Distribution of Immunoglobulins in Squamous Cell Carci- 97

noma of the Head and Neck

Neuchrist, C; Kornfehl, J.; Grasl, M.; Lassmann, H.; Kraft, D.; Ehrenberger, K; Scheiner, O.

Salivary IgE in Allergic Patients and Normal Donors 101

Vernejoux, J.M.; Tunon de Lara, J.M.; Villanueva, P.; Vuillemin, L.; Taytard, A.

Letter to the Editor

Topical Immunoglobulin G in Atopic Dermatitis

104

Burek-Kozlowska, A.; Morell, A.; Hunziker, T.

Modulation of Phenotypic and Functional Properties of Nor- 27 mal Human Mononuclear Phagocytes by Granulocyte-Macro-phage Colony-Stimulating Factor

Rivier, A.; Chanez, P.; Pène, J.; Michel, F.B.; Godard, Ph.; Dugas, B.; Bousquet, J.

Induction of Inflammatory Mediator Release (12-Hydroxyei- 33

cosatetraenoic Acid) from Human Platelets by Pseudomonas

aeruginosa

König, B.; Jaeger, K.-E.; König, W.

Oxygen Metabolites from Lavage and Interstitial Lung Cells

after Inhalation of Endotoxin in Guinea Pigs Hsieh, V.; Amoruso-Marchat, B.; Rylander, R.; Polla, B.S.

Immunophenotype of Lymphocytes in Pericardial Fluid from 48 Patients with Different Forms of Heart Disease Riemann, D.; Wollert, H.-G.; Menschikowski, J.; Mittenzwei, S.; Langner, J.

Isolation and Characterization of Group-I Isoallergens from 57

Bermuda Grass Pollen

Smith, P.M.; Avjioglu, A.; Ward, L.R.; Simpson, R.J.; Knox, R.B.;

Singh, M.B.

Epitope Mapping of Region $11-70$ of Ovalbumin \{Gal d $\backslash$ ) 65

Using Five Synthetic Peptides Elsayed, S.; Stavseng, L.

Enhancement of the Responsiveness of Vas Deferens and 72

Ileum Smooth Muscle in Sensitized Guinea Pigs: In vitro

Study 
Bidon, J.-C; Blin, M.; Gogny, M.; Vu, A.T.; Jondet, A.

Effect of Bovine Respiratory Syncytial Virus Infection on 79

Hypersensitivity to Inhaled Micropolysporafaeni Gershwin, L.J.; Himes, S.R.; Dungworth, D.L.;

Giri, S.N.; Friebertshauser, K.E.; Camacho, M.

Antiendothelial Cell Antibodies in Systemic Lupus erythema- 131

tosus: Enhanced Antibody Binding to Interleukin-1-Stimulated

Endothelium

van der Zee, J.M.; Miltenburg, A.M.M.; Siegert, C.E.H.; Daha, M.R.;

Breedveld, F.C.

Occurrence of IgG Subclass Antibodies to Ovalbumin, Avidin, 137 and Pneumococcal

Polysaccharide in Children Lim, P.L.; Lau, Y.L.

Antibodies to Dietary Antigen in Serum from Patients with 144

Sickle Cell Anemia

Malavé, I.; Perdomo, Y.; Rojas, I.; Pocino, M.; Malavé, H.; Carvajal, I.; Tlaskalová, H.

II

Correlation of Body Mass Index with Urinary Neopterin in 150

Individuals Infected with Human Immunodeficiency Virus Zangerle, R.; Sarcletti, M.; Gallati, H;

Reibnegger, G.; Wachter, H.; Fuchs, D.

Quantitation and Immunocytological Identification of Interleu- 155 kin-1 in Nasal Polyps from

Patients with Chronic Sinusitis Hamaguchi, Y.; Suzumura, H.; Arima, S.; Sakakura, Y.

Ole e I: Epitope Mapping, Cross-Reactivity with Other Olea- 160 ceae Pollens and

Ultrastructural Localization Martín-Orozco, E.; Cárdaba, B.; del Pozo, V.; de Andres, B.;

Villalba, M.; Gallardo, S.; Rodriguez-García, M.I.; Fernandez, M.C.; Alché, J.D.; Rodriguez, R.;

Palomino, P.; Lahoz, C.

Identification of Alpha-Amylase Inhibitor as a Major Allergen 171

of Wheat Flour

Fränken, J.; Stephan, U.; Meyer, H.E.; König, W.

Fusarium solani: Immunochemical Characterization of Aller- 175

gens

Verma, J.; Gangal, S.V.

Allergens in Hymenoptera Venom. XXVI: The Complete 184

Amino Acid Sequences of Two Vespid Venom Phospholipases Hoffman, D.R.

Abnormal IgG4 Antibody Response to Aeroallergens in Aller- 191 gic Patients

Jeannin, P.; Delneste, Y.; Tillie-Leblond, I.; Wallaert, B.; Carlier, A.; Pestel, J.; Tonnel, A.B.

Different Pattern of IgE Binding to Chicken Egg Yolk between 199 Patients with Inhalant

Allergy to Birds and Food-Allergic Children van Toorenenbergen, A.W.; Huijskes-Heins,

M.I.E.; van Wijk, R.G

Short Communications

Binding Properties of Protein A and Protein G for Human IgE 204 Peng, Z.; Becker, A.B.;

Simons, F.E.R.

Arylsulfatase B is present in Crystalloid-Containing Granules 207 of Human Eosinophil

Granulocytes Egesten, A.; Weller, P.F.; Olsson, I.

The Efficacy of Traditional Chinese Herbal Therapy in Atopic 222

Eczema 
Latchman, Y.; Whittle, B.; Rustin, M.; Atherton, D.J.; Brostoff, J.

Original Paper

HIV-1 gp41 Enhances Major Histocompatibility Complex 227

Class I and ICAM-1 Expression on H9 and U937 Cells Chen, BY.-H.; Böck, G; Vornhagen, R.;

Steindl, F.; Katinger, H; Dierich, M.P.

Long-Term in vitro Growth of Human T Cell Clones: 232

Can Postmitotic 'Senescent' Cell Populations Be Defined? Grubeck-Loebenstein, B.; Lechner, H.; Trieb, K.

Mast Cells Alter Granular Properties and Spatial Relation to 240 Nerve Fibres in Spondylitis of Adjuvant-Treated Rats Imai, S.; Hukuda, S.; Maeda, T.

Histochemical and Cytological Characterizations of Mucosal 249 and Connective Tissue Mast

Cells of Mongolian Gerbils (Meriones unguiculatus) Nawa, Y.; Horii, Y.; Okada, M.; Arizono, $\mathrm{N}$.

Increased Urinary Excretion of Angiotensin during Anaphylac- 255

toid Reactions

Rittweger, R.; Hermann, K.; Ring, J.

Lysine Residues in Bee Venom Phospholipase A2 Are Impor- 262 tant for Binding to Human

Monoclonal or Polyclonal Antibodies of the IgG4 Isotope Schneider, T.; Dudler, T.; Gelb, M.H.; Suter, M.

B Cell Mitogenic Activity of Sea Squirt Antigen 270

Segawa, K.; Ono, K.; Oka, S.; Jyo, T.; Kuroiwa, A.; Yamashita, U.

Cross-Reactivity of Ovine IgE with Anti-Human IgE 277

Yilmaz, H; Morgan, K.L.; Roe, J.M.

Cultivar-Specific Epitopes in Date Palm \{Phoenix dactylifera 281

L.) Pollenosis. Differential Antigenic and Allergenic Properties

of Pollen from Ten Cultivars

Kwaasi, A.A.A.; Parhar, R.S.; Tipirneni, P.; Harfi, H.A.;

Al-Sedairy, S.T.

Contribution of Intercellular-Adhesion Molecule-1 in Allergen- 291

Induced Airway Hyperresponsiveness and Inflammation in

Sensitised Brown-Norway Rats

Sun, J.; Elwood, W.; Haczku, A.; Barnes, P.J.; Hellewell, P.G.;

Chung, K.F.

Thimerosal Induces Toxic Reaction in Non-Sensitized 296

Animals

Uchida, T.; Naito, S.; Kato, H; Hatano I.; Harashima, A.; Terada, Y.;

Ohkawa, T.; Chino, F.; Eto, K.

Presence of Bronchoalveolar Lavage Fluid Necessary for Plate- 302 let Activating Factor-

Induced Ciliary Depression Ohashi, Y.; Ohno, Y.; Sugiura, Y.; Okamoto, H.; Tanaka, A.;

Kakinoki, Y.; Sakamoto, H.; Hayashi, M.; Nakai, Y.

Letter to the Editor

One of the Rubber Latex Allergens Has Lysozyme Activity 307

Yagami, T.; Sato, M.; Nakamura, A.; Shono, M.

Short Communication

Demonstration of the Presence of Coeliac-Activating Gliadin- 308

Like Epitopes in Malted Barley 
Ellis, H.J.; Doyle, A.P.; Day, P.; Wieser, H; Ciclitira, P.J.

317

No. 4

Mini Reviews

Recent Progress in the Elucidation of Interferon-Gamma 311

Actions: Molecular Biology and Biological Functions Vildek, J.; Oliveira, I.C.

Role of Interleukin-8 Receptor in Skin Kemény, L.; Ruzicka, T.; Dobozy, A.; Michel, G.

Original Paper

Role of Resident Peritoneal Cells in Eosinophil Migration 323

Induced by Saline

Oliveira, S.H.P.; Faccioli, L.H.; Cunha, F.Q.; Ferreira, S.H.

Beryllium-Induced Disturbances of the Murine Immune Sys- 332 tem Reflect Some Phenomena

Observed in Sarcoidosis Pfeifer, S.; Bartlett, R.; Strausz, J.; Haller, S.; Müller-Quernheim, J.

Modulation of Morphology, Proliferation and Collagen Synthe- 340 sis in Fibroblasts by the

Exudate from Hypersensitive Granulo-matous Inflammation in Rats Isaji, M.; Momose, Y.;

Tatsuzawa, Y.; Naito, J.

Serum Tryptase and Urinary 1-Methylhistamine as Parameters 348 for Monitoring Oral Food

Challenges in Children Beyer, K.; Niggemann, B.; Schulze, S.; Wahn, U.

Timing of Onset of Allergic Symptoms as a Response to a Dou- 352 ble-Blind, Placebo-

Controlled Food Challenge in Patients with Food Allergy Combined with a Radioallergosorbent Test and the Evaluation of Proliferative Lymphocyte Responses Fukutomi, O.; Kondo, N.;

Agata, H.; Shinoda, S.; Kuwabara, N.; Shinbara, M.; Orii, T.

Frequent Occurrence of IgE and IgG4 Antibodies against 366

Saliva of Aedes communis and Aedes aegypti Mosquitoes in

Children

Reunala, T.; Brummer-Korvenkontio, H.; Palosuo, K.; Miyamij, M.;

Ruiz-Maldonado, R.; Love, A.; Francois, G; Palosuo, T.

Lack of an Immune Response to Albunex ${ }^{\circledR}$, a New Ultrasound 372 Contrast Agent Based on

Air-Filled Albumin Microspheres Christiansen, C; Vebner, A.J.; Muan, B.; Vik, H.; Haider, T.;

Nicolaysen, H.; Skotland, T.

Histamine, Tryptase, Norepinephrine, Angiotensinogen, 379

Angiotensin-Converting Enzyme, Angiotensin I and II in Plasma of Patients with Hymenoptera Venom Anaphylaxis Hermann, K.; von Tschirschnitz, M.; Ebner von Eschenbach, C.; Ring, J.

Comparison of Vespula germanica Venoms Obtained from Dif- 385 ferent Sources

Sanchez, F.; Blanca, M.; Miranda, A.; Carmona, M.J.; Garcia, J.; Fernandez, J.; Torres, M.J.;

Rondon, M.C.; Juarez, C.

Analysis of IgG Subclass and IgE Response in Allergic Disease 390 Caused by Aspergillus

fumigatus by Immunoblotting Techniques Trompelt, J.; Becker, W.-M.; Schlaak, M.

Short Communications

Characterization of the 18-kDa Apple Allergen by Two-Dimen- 399 sional Immunoblotting and Microsequencing Vieths, S.; Schöning, B.; Petersen, A.

IgE-Specific Unresponsiveness in Mice Induced by Ovalbumin 405 Coupled with Murine Red Blood Cells Uchida, T.; Horino, A.; Naito, S.; Mizuguchi, J. 
Cord Blood Mononuclear Cell Responsiveness to Beta-Lacto-globulin: T-Cell Activity in 'Atopy-Prone' and 'Non-Atopy-Prone' Newborns Piastra, M.; Stabile, A.; Fioravanti, G.; Castagnola, M.; Pani, G; Ria, F.

358

Author Index Subject Index

409411

Suppl. 1

Eosinophils in Allergy

Guest Editors: Takeru Ishikawa, Kumamoto; Souhei Makino, Tochigi

S. Karger

Medical and Scientific Publishers Basel · Freiburg a Paris · London New York · New Delhi · Bangkok Singapore $\cdot$ Tokyo $\cdot$ Sydney

Drug Dosage

The authors and the publisher have exerted every effort to ensure that drug selection and dosage set forth in this text are in accord with current recommendations and practice at the time of publication. However, in view of ongoing research, changes in government regulations, and the constant flow of information relating to drug therapy and drug reactions, the reader is urged to check the package insert for each drug for any change in indications and dosage and for added warnings and precautions. This is particularly important when the recommended agent is a new and/or infrequently employed drug.

All rights reserved.

No part of this publication may be translated into other languages, reproduced or utilized in any form or by any means, electronic or mechanical, including photocopying, recording, microcopying, or by any information storage and retrieval system, without permission in writing from the publisher or, in the case of photocopying, direct payment of a specified fee to the Copyright Clearance Center (see 'Information for Readers and Subscribers').

(C) Copyright 1994 by S. Karger AG, P.O. Box, CH-4009 Basel (Switzerland) Printed in Switzerland on acid-free paper by Reinhardt Druck, Basel

IV

Contents 